\title{
ASSESSMENT OF MICROBIAL LOAD IN MARKETED BROILER MEAT AT MYMENSINGH DISTRICT OF BANGLADESH AND ITS PUBLIC HEALTH IMPLICATIONS
}

\author{
M. Mahmudul Hasan ${ }^{1}$, SM Lutful Kabir ${ }^{1 *}$, Nazmul Hoda $^{2}$ and M. Mansurul Amin ${ }^{1}$ \\ ${ }^{1}$ Department of Microbiology and Hygiene, Bangladesh Agricultural University, \\ Mymensingh-2202, Bangladesh; ${ }^{2}$ Veterinary Surgeon, Bangladesh National Zoo, Mirpur, \\ Dhaka, Bangladesh
}

*Corresponding author: SM Lutful Kabir, E-mail: Ikabir79@gmail.com

\section{ARTICLE INFO ABSTRACT}

\begin{tabular}{|c|c|}
\hline $\begin{array}{l}\text { Received } \\
02.03 .2015\end{array}$ & $\begin{array}{l}\text { An investigation was conducted to assess the bacteriological quality of } 30 \text { samples of } \\
\text { fresh broiler thigh meat samples sold in different retail markets in Mymensingh. Total } \\
\text { viable count (TVC), total coliform count (TCC), total salmonella count (TSC) and total }\end{array}$ \\
\hline Accepted & campylobacter count ( $\mathrm{TCpC}$ ) in meat samples of different broiler markets like K.R. at \\
\hline 12.04 .2015 & $\begin{array}{l}\text { BAU campus, Boyra and Kewatkhali were determined. Mean of TVC, TCC, TSC and } \\
\text { TCDC for the K.R. at BAU campus, Boyra and Kewatkhali markets were } 5.69,6.03 \text {, }\end{array}$ \\
\hline Online & $6.17 \log _{10} \mathrm{CFU} / \mathrm{g}, 4.52,4.66,4.69 \log _{10} \mathrm{CFU} / \mathrm{g}, 3.35,3.51,3.61, \log _{10} \mathrm{CFU} / \mathrm{g}$ and \\
\hline 19.04 .2015 & $\begin{array}{l}\text { 2.31, 2.56, } 2.66 \log _{10} \mathrm{CFU} / \mathrm{g} \text {, respectively. It was observed that the mean values of } \\
\text { TVC, TCC, TSC and TCPC in case of Boyra and Kewatkhali market exceeded the }\end{array}$ \\
\hline Key words & $\begin{array}{l}\text { ICMSF recommendations which may cause alarm to consumer's health. The variation } \\
\text { of TVC in meats of different broiler market was significant }(P<0.05) \text { at } 5 \% \text { level of }\end{array}$ \\
\hline Bacterial load & probability whereas TCC and TSC obtained from meat samples of different markets \\
\hline Broiler meat & were not showed significant $(P>0.05)$. The mean values of $T C p C$ in meats of three \\
\hline Broiler market & significant with $1 \%$ level of probability $(P<0.01)$. There \\
\hline Public health & $\begin{array}{l}\text { was no significant correlation found between TVC and TCC }(\mathrm{P}>0.05) \text {, but a } \\
\text { significant correlation found between TVC with TSC and TVC with TCpC in meats of } \\
\text { three different markets respectively. Presence of Escherichia coli, Campylobacter and } \\
\text { Salmonella spp. in meats must receive particular attention, as these organisms are } \\
\text { responsible for causing harm to public health. Suggestion has been given to improve } \\
\text { the present sanitary condition of meat processing to minimize bacterial load. }\end{array}$ \\
\hline
\end{tabular}

To cite this article: MM Hasan, SML Kabir, N Hoda and MM Amin. 2015. Assessment of microbial load in marketed broiler meat at Mymensingh district of Bangladesh and its public health implications. Res. Agric. Livest. Fish. 2 (1): 87-95.

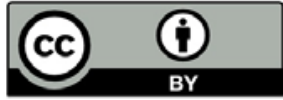




\section{INTRUDUCTION}

Chicken is one of the most widely used delicious and versatile meats in the world largely because its protein is of excellent quality and contains all the essential amino acids needed by man. At present broiler is the cheapest meat source in Bangladesh and it contributes about 30\% to the total animal protein for human consumption (Huque, 1996). Although small scale commercial boiler farms are gradually rising due to their production yield in shortest period of time and low investment. But contamination of poultry meat with food borne pathogens remains an important health hazardous issue, because of the practices of handling and management during in slaughtering, cooking or post cooking storage of the product (Javadi and Safarmashaei, 2011). Meat was the first important food that met up the hunger of ancient people living in cave (Johanson et al., 1983). It plays a very vital role in keeping the human body strong in order to provide energy, health and vigour (Rahman, 2000).

Meat obtained from chicken does not only undergo spoilage, but may also frequently been found implicated in the spread of food-borne illnesses. If hygienic care is not maintained during the various stages of slaughter operations and processing, the potential edible tissues get subjected to contamination from a variety of sources within and outside the animal and also from the environment, equipment and operators. Morethan 30 genera of micro-organisms including seven pathogens (E. coli O157:H7, Campylobacter, Salmonella, Clostridium perfringens, Listeria monocytogenes, Staphylococcus aureus, are known to contaminate poultry products. Since poultry meat itself offers an excellent medium for the multiplication of most bacteria, including those that are not inhibited by low temperatures, storage of processed poultry meat is vital and therefore considered only under circumstances which inhibit the multiplication of the initial load of bacteria (Adu-Gyamfi et al., 2012). In recent years, food borne infections and intoxications have assumed significance as a health hazard. Epidemiological reports suggest that poultry meat is still the primary cause of human food poisoning (Mulder, 1999). Poultry meat is more popular in the consumer market because of advantages such as easy digestibility and acceptance by the majority of people (Yashoda et al. 2001). However, the presence of pathogenic and spoilage microorganisms in poultry meat and its by-products remains a significant concern for suppliers, consumers and public health officials worldwide. Bacterial contamination of these foods depends on the bacterial level of the poultry carcasses used as the raw product, the hygienic practices during manipulation and on the time and temperature of storage (El-Leithy and Rashad, 1989). However, the control and inspection during production, storage and distribution are generally rare. It is important to prevent the hazards and to provide a safe and wholesome product for human consumption (Singh et al., 1984). Therefore, an investigation was conducted to assess the bacteriological quality of fresh broiler thigh meat samples sold in different retail markets in Mymensingh.

\section{MATERIALS AND METHODS}

\section{Sources, collection and transportation of samples}

This experiment was carried out in the Microbiology Laboratory of Bangladesh Agricultural University, Mymensingh from 1 January to 1 April, 2014. All samples were obtained from local retail markets situated in K.R. market at BAU campus, Boyra and Kewatkhali market. The attendant first immersed the slaughtered broilers in a special tank containing hot water for some time. The immersed birds were defeathered traditionally by hand plucking and subsequently evisceration was done using special tricks or techniques. Then cut the thigh region muscle and put into a sterilized container. Samples were collected aseptically in sterile containers and brought to the laboratory within 30 minutes to determine the TVC and occurrences of different microflora gaining access to meat. During transportation the sterile containers were kept cool in iceboxes containing fragments of ice. 


\section{Preparation of sample for bacteriological studies}

Each of the raw meat samples was macerated in a mechanical blender using a sterile diluent as per recommendation of International Organisation for Standardisation (ISO, 1995). Ten grams of the thigh meat sample was taken aseptically with a sterile forceps and transferred into sterile containers containing $90 \mathrm{ml}$ of $0.1 \%$ peptone water. A homogenized suspension was made in a sterile blender. Thus 1:10 dilution of the samples was obtained. Later on using whirly mixture machine different serial dilutions ranging from $10^{-2}$ to $10^{-6}$ were prepared according to the standard method (ISO, 1995).

\section{Enumeration of TVC}

For the determination of total bacterial count, $0.1 \mathrm{ml}$ of each ten-fold dilution was transferred and spread on duplicate PCA using a fresh pipette for each dilution. The diluted samples were spread as quickly as possible on the surface of the plate with a sterile glass spreader. One sterile spreader was used for each plate. The plates were then kept in an incubator at $37^{\circ} \mathrm{C}$ for $24-48$ hours. Following incubation, plates exhibiting 30-300 colonies were counted. The average number of colonies in a particular dilution was multiplied by the dilution factor to obtain the total viable count. The TVC was calculated according to ISO (1995). The results of the total bacterial count were expressed as the number of organism or colony forming units per gram (CFU/g) of meat sample.

\section{Enumeration of TCC}

For the determination of TCC, $0.1 \mathrm{ml}$ of each ten-fold dilution was transferred and spread on Mac Conkey agar using a sterile pipette for each dilution. The diluted samples were spread as quickly as possible on the surface of the plate with a sterile glass spreader. One sterile spreader was used for each plate. The plates were then kept in an incubator at $37^{\circ} \mathrm{C}$ for $24-48$ hours. Growth of the organism was confirmed by the appearance of turbidity. Results were calculated from MPN tables.

\section{Enumeration of TSC}

For the determination of total salmonella count the procedures of sampling, dilution and streaking were similar to those followed in total viable bacterial count. Only in case of salmonella count, xylose lysine deoxycholate agar (XLDA) was used. The calculation for TSC was similar to that of total viable count.

\section{Enumeration of TCpC}

For the determination of $\mathrm{TCpC}, 0.1 \mathrm{ml}$ of each ten-fold dilution was transferred and spread on the selective blood base agar with $5 \%$ sheep or cattle blood. The diluted samples were spread as quickly as possible on $0.45 \mathrm{~mm}$ filter placed on blood agar base agar no 2 with a sterile glass spreader. The plates were then kept in an incubator at $42^{\circ} \mathrm{C}$ for $24-48$ hours. Following incubation, plates exhibiting 30-300 colonies were counted. The average number of colonies in a particular dilution was multiplied by the dilution factor to obtain the total viable count. The total viable count was calculated according to ISO (1995). The results of the total bacterial count were expressed as the number of organism or colony forming units per gram (CFU/g) of meat sample. In young culture the organism is comma shaped and S shaped. In old culture organisms cling together. Gram -ve colonies were round, smooth and translucent with a dewdrop appearance.

\section{Cultural and biochemical examination of samples}

The cultural examination of chicken thigh meat samples for bacteriological analysis was done according to the standard method (ICMSF, 1985). The examination followed detail study of colony characteristics including the morphological and biochemical properties. In order to find out different types of microorganisms in chicken thigh meat samples, different kinds of bacterial colonies were isolated in pure culture from the plate count agar (PCA), Mac Conkey agar (MCA), blood agar (BA) and xylose lysine deoxycholate agar (XLDA) and subsequently identified according to the methods described by Krieg et al., 1994. The isolated organisms with supporting growth characteristics on various media were subjected to different biochemical tests such as sugar fermentation test, indole production test, catalase test, coagulase test, methyl-red and Voges-Proskauer (VP) test. In all cases standard methods as described by Cowan (1985) were followed for conducting these tests. 


\section{Statistical analysis of experimental data}

The data on TVC, TCC, TSC and TCPC obtained from the bacteriological examination of meat samples of the poultry carcass collected from different area of Mymensingh district were analysed in completely randomised design (CRD) using computer package subjected to Analysis of Variance using SPSS Software (Version 16, 2007). The differences between means were evaluated by Duncan's Multiple Range Test (Gomez and Gomez, 1984). Correlation between TVC, TCC, TSC and TCpC were also evaluated.

\section{RESULTS AND DISCUSSION}

The mean and standard deviation of the TVC in broiler thigh meats of K.R. market, Boyra and Kewatkhali markets are presented in Tables 1, 2 and 3. The variation of TVC in meats of different broiler market was significant $(P<0.05)$ at $5 \%$ level of probability as shown in Table 4 . The result of TVC in three different retail markets were differed significantly $(\mathrm{P}<0.05)$. The maximum and minimum range of TVC in thigh meat recorded at K.R. market, Boyra and Kewatkhali markets were $\log 6.2, \log 6.69, \log 6.6$ and $\log 5.25, \log 5.28$, $\log 5.77$, respectively (Table 5). However the average value of TVC at three markets are $\log 5.72, \log 5.93$ and log 6.18 as shown in Table 5. In K.R. market the value of TVC was lower than Boyra market but it is highest in Kewatkhali market shown in Tables 1, 2 and 3. The possible cause of this variation in microbial load might be thought to be due to differences in management and hygienic practices. Observation of the investigation revealed the fact that in case of K.R. market, the slaughter hygiene and process of broiler meat production was relatively more hygienic in respect of sanitation and handling systems. The butchers generally are skilled and the consumers are well conscious about risk factors and hazardous elements associated with meat production and handling. On the contrary in Kewatkhali markets these are not so, rather the butchers are unskilled and illiterate and the consumers mostly are poor and do not hesitate to purchase poor quality meat. The results obtained were in close agreement with the findings of Adu-Gyamfi et al. (2012), Anwar et al. (2004) and Abu-Ruwaida et al. (1994).

The mean and standard deviation of the TCC of broiler meat processed at slaughter yards of K.R, Boyra, and Kewatkhali markets are summarized in Tables 1, 2 and 3. The result evaluated in Table 4 revealed that the mean values of TCC in meats of K.R. market, Boyra and Kewatkhali market were not significant $(P>0.05)$. Nevertheless no significant variation was demonstrated between the interactions of the three markets. The interpretation of TCC in three different retail markets were not differed significantly (Table 4). The maximum and minimum range of TCC in thigh meat recorded at K.R. market, Boyra and Kewatkhali markets were $\log 5.1, \log 4.96, \log 5.15$ and $\log 4.25, \log 4.28, \log 4.28$, respectively (Table 5). However the average value of TCC at three markets were $\log 4.67, \log 4.62$ and $\log 4.71$ as shown in Table 5. These findings were agreement with the observations of Datta et al. (2012) and Abu-Ruwaida et al. (1994), respectively. In a study Altabari and Al-Dughaym (2002) and Ahmad et al. (2013) identified lower coliform count of log 3.8 and log 2.94 CFU/ gm, respectively.

The mean values of TSC in broiler meat of three different area like K.R. market at BAU campus Market, Boyra Market and Kewatkhali Market are summarized in Tables 1, 2 and 3. The mean values of TSC in broiler meat of three different area like K.R. market at BAU campus Market, Boyra Market and Kewatkhali Market were $\log 3.35 \pm 0.57, \log 3.51 \pm 0.22$ and $\log 3.61 \pm 0.76 \mathrm{CFU} / \mathrm{g}$ respectively (Table 4). The variation of TSC in meats of different market area was not significant $(P>0.05)$ presented in Table 4. The interpretation of TSC in three different retail markets were not differed significantly $(P>0.05)$. The maximum and minimum range of TSC in thigh meat recorded at K.R., Boyra and Kewatkhali markets were $\log 3.9, \log 3.8, \log 4.3$ and $\log$ 2.75, $\log 3.25, \log 3.1$ respectively (Table 5). However the average value of TSC at three markets were log 3.32, $\log 3.47$ and $\log 3.7$ as shown in Table 5. The TSC value in K.R market was lower than Boyra market but it is highest in Kewatkhali market. This signifies the fact that all these meats are more or less handled in the same manner. The findings are also closely related to the findings of several other researchers (Mead et al.1994 and Boonmar et al. 1998). 
The mean values of TCpC in broiler meat of three different markets like K.R. market, Boyra and Kewatkhali Markets are summarized in Tables 1, 2 and 3. The mean values of TCpC in broiler meat of three different markets like K.R, Boyra and Kewatkhali Markets were $\log 2.31 \pm 0.16, \log 2.56 \pm 0.03$ and $\log 2.66 \pm$ $0.07 \mathrm{CFU} / \mathrm{g}$ respectively (Table 4). The result presented in Table 4 revealed that the mean values of TCpC in meats of K.R. market, Boyra and Kewatkhali market were highly significant with $1 \%$ level of probability $(P<0.01)$. Similarly this variation of $\mathrm{TCpC}$ is observed in meats of different broiler carcass as significant $(P<0.05)$. The value of Total Campylobacter Count in three different retail markets were differed significantly $(P<0.01)$.The maximum and minimum range of TSC in thigh meat estimated at K.R. market, Boyra and Kewatkhali markets were $\log 2.56, \log 2.77, \log 3.2$ and $\log 2, \log 2.5, \log 2.1$ respectively evaluated in Table 5. Whatever the average value of TSC at three markets a $\log 2.28, \log 2.62$ and $\log 2.65$ evaluated in Table 5. The TCpC value of K.R. market is lower than Boyra market but it is highest in Kewatkhali market. These findings have proximal relationship with the findings of Isohanni (2013) and Park et al. (1981).On the otherhand Bodhidatta et al. (2013) found higher TCpC value from fresh broiler meat and was log 2.5 to log 3.1 .The value of TCpC at K.R market of BAU campus is lowest (log 2.31) and highest in Kewatkhali market (log 2.66), the findings are also very much close to Federighi et al. (1995), Bjorkroth et al.(2000) and Shane et al. (2000) respectively. A significant and positive correlation was found in TCpC at different retail markets with different broiler meat. A highest result 5.33 log 10 c.f.u. per carcass, respectively noted by Cason et al. (1997).

The result estimated in Figure 1 showed weakly correlated between the TVC and TCC. In this study, viable counts were did not significantly correlated with total coliform count in three market area. The regression equation and correlation coefficient values were, $y=-0.1323 x+6.5798$., and $R^{2}=0.0088$ as shown in Fig. 1. The result shown in figure 2 revealed that the regression was positively correlated with TVC and TSC in different market, where correlation coefficient was $R^{2}=0.0377$ and regression equation was $y=0.2419 x+$ 5.1227 , respectively. Hence the increase of TVC will enhance by the increase of TSC abruptly the decrease of TVC will be decrease with the TSC count (Figure 2). The result evaluated in figure 3 showed positively and significantly correlated between the viable count and total Campylobacter count in three market place. The regression equation and correlation coefficient values were $y=0.5741 x+4.5265$ and $R^{2}=0.1468$, respectively (Figure 3). It seems that a significant relation were found between TVC and TCpC respectively.

Table 1. Enumeration of microbial load in broiler meat obtained from K.R market of BAU Campus.

\begin{tabular}{|c|c|c|c|c|c|}
\hline \multirow{2}{*}{ Place of collection } & \multirow{2}{*}{$\begin{array}{l}\text { Sample } \\
\text { no. }\end{array}$} & \multicolumn{4}{|c|}{ Microbial load } \\
\hline & & $\begin{array}{l}\text { TVC } \\
\text { (CFU/g) }\end{array}$ & $\begin{array}{l}\text { TCC } \\
\text { (CFU/g) }\end{array}$ & $\begin{array}{l}\text { TSC } \\
\text { (CFU/g) }\end{array}$ & $\begin{array}{l}\text { TCpC } \\
\text { (CFU/gm) }\end{array}$ \\
\hline \multirow{10}{*}{ K.R. Market } & 1 & 5.8 & 4.63 & 3.9 & 2.1 \\
\hline & 2 & 5.57 & 5.0 & 3.83 & 2.0 \\
\hline & 3 & 5.4 & 4.25 & 3.26 & 2.34 \\
\hline & 4 & 5.25 & 4.55 & 3.38 & 2.44 \\
\hline & 5 & 5.3 & 5.1 & 3.15 & 2.2 \\
\hline & 6 & 5.8. & 4.35 & 3.36 & 2.5 \\
\hline & 7 & 6.0 & 3.9 & 3.65 & 2.13 \\
\hline & 8 & 6.1 & 4.5 & 2.75 & 2.47 \\
\hline & 9 & 5.55 & 4.56 & 3.2 & 2.56 \\
\hline & 10 & 6.2 & 4.4 & 3.1 & 2.33 \\
\hline Mean \pm SD & & $5.69 \pm 0.28$ & $4.52 \pm 0.16$ & $3.35 \pm 0.57$ & $2.31 \pm 0.16$ \\
\hline
\end{tabular}

All counts are expressed in logarithms and CFU/g of meat. 
Table 2. Enumeration of microbial load in broiler meat obtained from Boyra Market.

\begin{tabular}{|llllll|}
\hline \multirow{2}{*}{ Place of collection } & Sample & \multicolumn{3}{c|}{ Microbial load } \\
\cline { 3 - 6 } & no. & TVC & TCC & TSC & TCpC \\
(CFU/g) & (CFU/g) & (CFU/g) & (CFU/g) \\
\hline & 1 & 5.9 & 4.7 & 3.56 & 2.6 \\
& 2 & 5.28 & 4.68 & 3.35 & 2.56 \\
Boyra Market & 3 & 5.39 & 4.89 & 3.65 & 2.36 \\
& 4 & 5.8 & 4.77 & 3.70 & 2.77 \\
& 5 & 6.45 & 4.95 & 3.68 & 2.8 \\
Mean \pm SD & 6 & 6.29 & 4.45 & 3.29 & 2.45 \\
& 7 & 5.93 & 4.35 & 3.45 & 2.5 \\
& 8 & 6.37 & 4.65 & 3.43 & 2.66 \\
& 9 & 6.28 & 4.88 & 3.7 & 2.4 \\
\hline
\end{tabular}

All counts are expressed in logarithms and CFU/g of meat.

Table 3. Enumeration of microbial load in broiler meat obtained from Kewatkhali market.

\begin{tabular}{|c|c|c|c|c|c|c|}
\hline \multirow{2}{*}{$\begin{array}{l}\text { Place } \\
\text { collection }\end{array}$} & \multirow{2}{*}{ of } & \multirow{2}{*}{$\begin{array}{l}\text { Sample } \\
\text { no. }\end{array}$} & \multicolumn{4}{|c|}{ Microbial load } \\
\hline & & & $\begin{array}{l}\text { TVC } \\
\text { (CFU/g) }\end{array}$ & $\begin{array}{l}\text { TCC } \\
\text { (CFU/g) }\end{array}$ & $\begin{array}{l}\text { TSC } \\
(\mathrm{CFU} / \mathrm{g})\end{array}$ & $\begin{array}{l}\text { TCpC } \\
\text { (CFU/g) }\end{array}$ \\
\hline & & 1 & 6.32 & 4.66 & 4.3 & 2.66 \\
\hline & & 2 & 6.45 & 5.15 & 3.8 & 3.1 \\
\hline & & 3 & 6.2 & 4.78 & 3.4 & 2.55 \\
\hline & & 4 & 5.8 & 4.65 & 3.67 & 2.8 \\
\hline Kewatkhali & & 5 & 6.15 & 4.8 & 3.56 & 3.2 \\
\hline \multirow[t]{5}{*}{ Market } & & 6 & 5.77 & 5.0 & 3.29 & 2.1 \\
\hline & & 7 & 6.6 & 4.36 & 4.1 & 2.44 \\
\hline & & 8 & 5.98 & 4.28 & 3.69 & 2.5 \\
\hline & & 9 & 6.05 & 4.5 & 3.10 & 2.7 \\
\hline & & 10 & 6.46 & 4.76 & 3.22 & 2.56 \\
\hline Mean $\pm S D$ & & & $6.17 \pm 0.09$ & $4.69 \pm 0.07$ & $3.61 \pm 0.76$ & $2.66 \pm 0.07$ \\
\hline
\end{tabular}

All counts are expressed in logarithms and CFU/g of meat. 
Table 4. Determination of mean and standard deviation for statistical analysis of microbiological quality of chicken thighs at different retail markets in Mymensingh.

\begin{tabular}{|lllll|}
\hline Retail Market & TVC & TCC & TSC & TCpC \\
& Mean \pm SD & Mean \pm SD & Mean \pm SD & Mean \pm SD \\
\hline K.R. Market & $5.69 \pm 0.28^{\mathrm{b}}$ & $4.52 \pm 0.16^{\mathrm{a}}$ & $3.35 \pm 0.57^{\mathrm{a}}$ & $2.31 \pm 0.16^{\mathrm{b}}$ \\
Boyra Market & $6.03 \pm 0.49^{\mathrm{ab}}$ & $4.66 \pm 0.29^{\mathrm{a}}$ & $3.51 \pm 0.22^{\mathrm{a}}$ & $2.56 \pm 0.03^{\mathrm{a}}$ \\
Kewatkhali Market & $6.17 \pm 0.09^{\mathrm{a}}$ & $4.69 \pm 0.07^{\mathrm{a}}$ & $3.61 \pm 0.76^{\mathrm{a}}$ & $2.66 \pm 0.07^{\mathrm{a}}$ \\
LSD & 0.35 & 0.28 & 0.31 & 0.22 \\
Level of sig. & $*$ & NS & NS & $* *$ \\
\hline
\end{tabular}

* = Single asterisk $\left({ }^{*}\right)$ means Significant at $5 \%$ level of probability; ${ }^{* \star}=$ Double asterisk $\left({ }^{*}\right)$ means Significant at $1 \%$ level of probability; NS = Not significant

In a column figures with same letter do not differ significantly $(p>0.05)$ whereas figures with dissimilar letter differ significantly (as per DMRT)

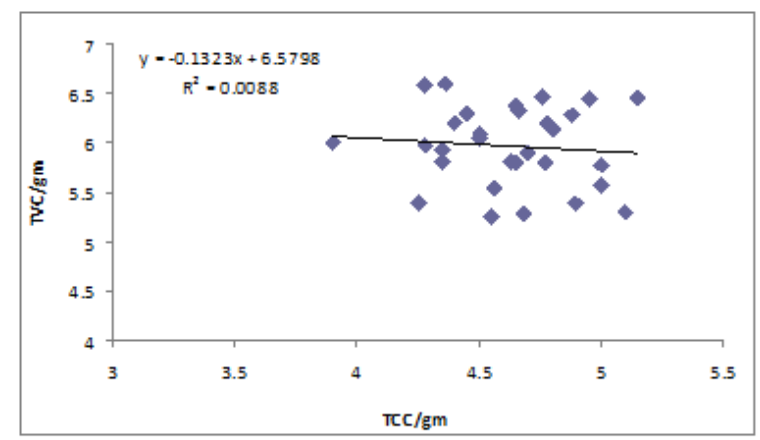

Figure 1. Correlation between TVC and TCC in CFU/g meat of three different retail market

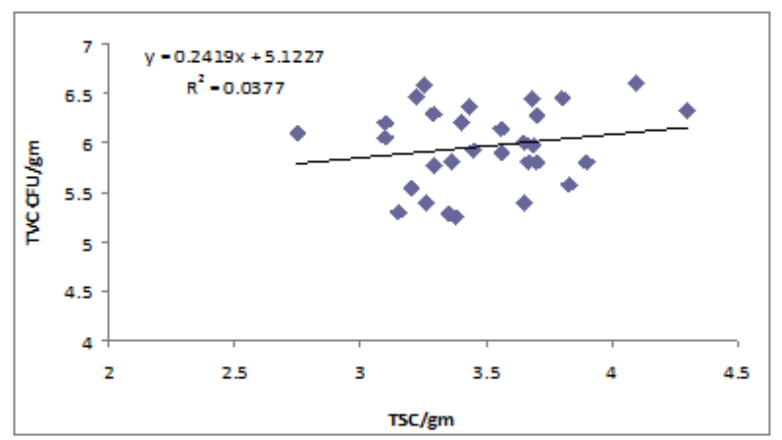

Figure 2. Relationship between TVC and TSC in CFU/g meat of different market area

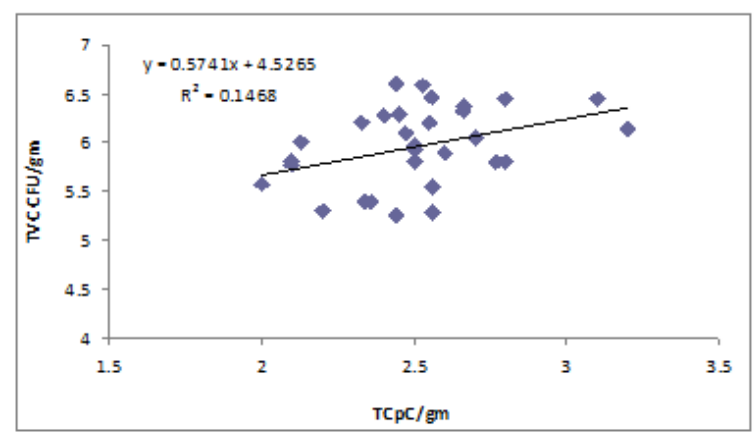

Figure 3. Relationship between TVC and TCpC in CFU/gm meat of different retail market 
Table 5. Range of total viable bacteria, coliform, salmonella and campylobacter count in broiler meats obtained from K.R. at BAU, Boyra and Kewatkhali markets.

\begin{tabular}{|c|c|c|c|c|c|c|c|c|c|c|c|c|c|}
\hline \multirow[b]{2}{*}{ Source } & \multirow[b]{2}{*}{ Examine } & \multicolumn{3}{|l|}{ TVC } & \multicolumn{3}{|l|}{ TCC } & \multicolumn{3}{|l|}{ TSC } & \multicolumn{3}{|c|}{ TCpC } \\
\hline & & Max & Min & Av. & Max & Min & Av. & Max & Min & Av. & Max & Min & Av. \\
\hline $\begin{array}{l}\text { K.R. } \\
\text { market }\end{array}$ & Thigh & 6.2 & 5.25 & 5.72 & 5.1 & 4.25 & 4.67 & 3.9 & 2.75 & 3.32 & 2.56 & 2.0 & 2.28 \\
\hline $\begin{array}{l}\text { Boyra } \\
\text { Market }\end{array}$ & Thigh & 6.59 & 5.28 & 5.93 & 4.95 & 4.28 & 4.61 & 3.70 & 3.25 & 3.47 & 2.77 & 2.5 & 2.62 \\
\hline $\begin{array}{l}\text { Kewatk- } \\
\text { ali } \\
\text { market }\end{array}$ & Thigh & 6.6 & 5.77 & 6.18 & 5.15 & 4.28 & 4.71 & 4.3 & 3.1 & 3.70 & 3.2 & 2.1 & 2.65 \\
\hline
\end{tabular}

All counts are expressed in logarithms and CFU/gm of meat; Av. = Average

\section{CONCLUSIONS}

Bacterial genera identified in this study are known as food borne bacteria which may cause food borne infection and intoxication. The study revealed that the mean values of TVC, TCC, TSC and TCpC of K.R. market was lower than the other two related markets. On the basis of bacterial load K.R. market at BAU campus, Boyra and Kewatkhali markets were graded as A, B and C respectively. Presence of Escherichia coli, Salmonella and Campylobacter in meat must receive particular attention, as these organisms are responsible for causing hazard to public health. These high levels of microbial contamination reflect the poor hygienic quality of poultry meat.

\section{ACKNOWLEDGEMENTS}

We are grateful to Professor Dr. M. Mufizur Rahman, Department of Microbiology and Hygiene, Bangladesh Agricultural University, Mymensingh, Bangladesh for critically reading the manuscript.

\section{REFERENCES}

1. Abu-Ruwaida AS, WN Sawaya, BH Bashti, M Murad and HA Al-Othman, 1994. Microbiological quality of broilers during processing in a modern commercial slaughterhouse in Kuwait. Journal of Food Protection, 57: 887-892.

2. Adu-Gyamfi A, W Torgby-Tetteh and V Appiah, 2012. Microbiological Quality of Chicken Sold in Accra and Determination of D10-Value of E. coli. Food and Nutrition Sciences, 3: 693-698.

3. Ahmad MUD, A Sarwar, MI Najeeb, M Nawaz, AA Anjum, MA Ali and NM Ansur, 2013. Assessment of Microbial load of raw meat at abattoir and retail. The Journal of Animal \& Plant Sciences, 23: 745-748.

4. Altabari G and AM Al-Dughaym, 2002. The role of sanitary inspection of meat in relation of food poisoning. In: The Second Annual Scientific Meeting for Environment Hygiene (Meat Hygiene), Riyadh, pp. 180-203.

5. Anower AKMM, MM Rahman, MA Ehsan, MA Islam, MR Islam, GC Shil and MS Rahman, 2004. Bacteriological profile of dressed broilers and its public health implications. Bangladesh Journal of Veterinary Medicine, 2: 69-73.

6. Bjorkroth KJ, R Geisen, U Schillinger, N Weiss, P De-Vos, WH Holzapfel, HJ Korkeala and P Vandamme, 2000. Characterization of Leuconostoc gasicomitatum sp. nov. associated with spoiled raw tomato-marinated broiler meat strips packaged under modified atmosphere conditions. Applied and Environmental Microbiology, 66: 3764-3772.

7. Bodhidatta L, P McDaniel and S Sornsakrin, 2010. Case-control study of diarrheal disease etiology in a remote rural area in Western Thailand. The American Journal of Tropical Medicine and Hygiene, 83: 1106-9. 
8. Boonmar S, A Bangtrakulnonth, S Pornrunangwong, N Marnrim, K Kaneko and M Ogawa, 1998. Salmonella in broiler chickens in Thailand with special reference to contamination of retail meat with salmonella enteritis. Journal of Veterinary Medical Science, 60: 1233-1236.

9. Cason JA, JS Bailey, NJ Stern, AD Whittemore and NA Cox, 1997. Relationship between aerobic bacteria, salmonellae and campylobacter on broiler carcasses. Poultry Science, 76: 1037-1041.

10. Cowan ST 1985. Cowan and Steel's Manual for Identification of Bacteria (2nd edn.). Cambridge University Press. Cambridge, London.

11. Datta S, A Akter, IG Shah, K Fatema, TH Islam, A Bandyopadhyay, ZUM Khan and D Biswas, 2012. Microbiological quality assessment of raw meat and meat products, and antibiotic susceptibility of isolated Staphylococcus aureus. Agriculture, Food and Analytical Bacteriology, 2: 187-194.

12. El-Leithy MA and FM Rashad, 1989. Bacteriological studies on ground meat and its products. Archiv für Lebensmittel Hygiene, 40: 58-61.

13. Federighi M, JM Cappelier, A Rossero, P Cappen and JC Denis, 1995. Assessment of the effect of a decontamination process of broiler carcasses on thermotolerant campylobacters. Sciences-desAliments, 15: 393-401.

14. Gomez KA and AA Gomez, 1984. Statistical procedures for agricultural research. John Wiley and sons, Inc. London, UK (2 $2^{\text {nd }}$ edtn)

15. Huque QME, 1996. Improving Skills of the small farmers in poultry management. Poultry Science, 35 : 412-418.

16. ICMSF, 1985. Microorganism in foods; samples for Microbiological Analysis: Principles and specific applications. Recommendation of the International Commission on Microbiological Specification for Foods. Association of Microbiological Societies. Toronto, University of Toronto Press.

17. ISO, 1995. Recommendation of the meeting of the subcommittee, International Organization for Standardization, on meat and meat products. ISO/TC-36/Sc-6. The Netherlands. 10-18.

18. Isohanni P, S Huehn, T Aho, T Alter and U Lyhs, 2013. Heat stress adaptation induces crossprotection against lethal acid stress conditions in Arcobacter butzleri but not in Campylobacter jejuni. Food Microbiology, 34:431-435.

19. Javadi A and S Safarmashaei, 2011. Study of Enterobacteriacea contamination level in premises of poultry slaughterhouse with HACCP system. Journal of Animal and Veterinary Advances, 10: 21632166.

20. Johanson L, B Underdal, K Grosland, OP Whelehan and TA Roberts, 1983. A survey of the hygienic quality of beef and pork carcasses in Norway. Acta Veterinaria Scandinavica, 24: 1113.

21. Mead GC, WR Hudson and MH Hinton, 1994. Use of a marker organism in poultry processing to identify sites of cross contamination and evaluate possible control measures. British Poultry Science, 35:345-354.

22. Mulder RW 1999. Hygiene during transport, slaughter and processing. In: Poultry Meat Science. Poultry Science Symposium Series (Richardson and Mead eds). CABI Publishing, 25: 277-285.

23. Krieg NR, JG Holt, PHA Sneath, JT Staley and ST Williams, 1994. Bergey's Manual of Determinative Bacteriology, Williams \& Wilkins, Baltimore, Md, USA, 9th edition.

24. Park CE, ZK Stankiewicz, J Lovett and J Hant, 1981. Incidence of campylobacter jejune in frets eviscerated whole market chickens. Canadian Journal of Microbiology, 27: 841-842.

25. Rahman MM, 2000. Fundamentals of Meat Hygiene. Bismillah Farming and Frozen Meat Ltd. Dhaka, pp. 76-101.

26. Shane SM 2000. Campylobacter infection of commercial poultry: Rev Sci Tech Off Int Epiz, 19: 376395.

27. Singh RD, LN Mandal and JN Pandey, 1984. Isolation of aerobic microorganisms from poultry meat at central poultry farm and retail shop. Patna Poult Guide, 21: 71-74.

28. Yashoda KP, NM Sachindra, PZ Sakhare and DN Rao, 2001. Microbiological quality of broiler chicken carcasses processed hygienically in a small scale poultry processing unit. Journal of Food Quality, 24: 249-259. 